\title{
THE PERSISTENCY AND THE SUSTAINABILITY OF THE INDONESIA'S CURRENT ACCOUNT DEFICIT
}

\author{
Tuti Eka Asmarani \\ Telisa Aulia Falianty ${ }^{2}$
}

\begin{abstract}
This paper is motivated by the current account deficit in Indonesia's, notably since 2011Q4. The aim of this paper is to test if this deficit is persistent and sustainable. Using stationary and Autoregressive Distributed Lag (ARDL) approach, the result shows the Indonesian current account deficit is persistent for the period of 2011Q4-2014Q1, and is considered to be unsustainable. These two findings call the government to optimize the policy on supporting the export performance, and transport services in particular.
\end{abstract}

Keywords: Current account deficit, random walk, intertemporal budget constraint, unit root, ARDL. JEL Classification: C22, F32, F41

1 Author is graduated from Postgraduate Program, Department of Economic, University of Indonesia, and is a lecturer at University of Gunadarma (tutiekasmarani@ymail.com).

2 Author is Director of Master Planning and Public Policy FE UI and lecturer at Department of Economics FE UI. 


\section{PENDAHULUAN}

Neraca transaksi berjalan merupakan salah satu indikator penting dalam menunjukkan performance makroekonomi suatu negara dari sisi eksternal, yang juga merupakan cerminan dari perekonomian internal, seperti ekspor dan impor di sektor rill, serta penerimaan dan pengeluaran di sektor fiskal (pemerintah). Neraca transaksi berjalan yang positif (surplus) mencerminkan bahwa negara tersebut meminjamkan kelebihan tabungannya ke luar negeri, sehingga stok net aset bertambah, sedangkan neraca transaksi berjalan yang negatif (defisit) mengimplikasikan negara tersebut kekurangan dana tabungan untuk investasi domestik, sehingga harus meminjam/berutang ke negara lain.

Defisit/surplus neraca transaksi berjalan dapat menyebabkan keuntungan dan kerugian dalam jangka panjang dan jangka pendek. Surplus neraca transaksi berjalan dalam jangka pendek memberikan keuntungan, karena negara akan memperoleh pendapatan berupa bunga pinjaman dari hasil investasi ke luar negeri, namun memberikan kerugian dalam jangka panjang, karena stok tabungan domestik menjadi berkurang akibat adanya investasi ke luar negeri secara besar-besaran. Alhasil, pembangunan negara menjadi terganggu. Sedangkan defisit yang menguntungkan dalam jangka pendek, karena adanya pinjaman/utang luar negeri yang dapat digunakan untuk membiayai investasi domestik namun merugikan dalam jangka panjang karena defisit neraca transaksi berjalan dapat membawa pada kondisi krisis ekonomi yang serius (Polat, 2011).

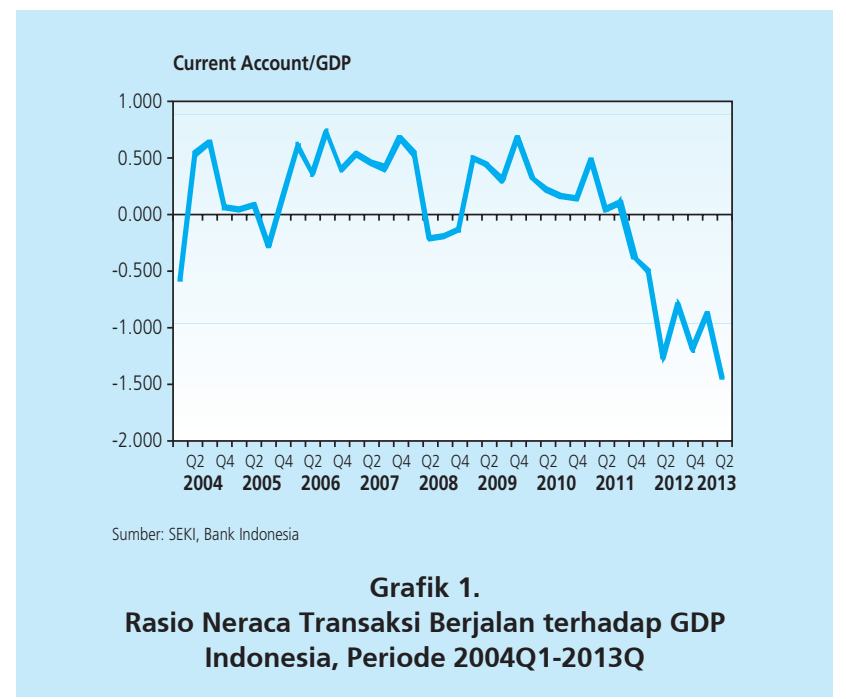

Jika dilihat berdasarkan grafik rasio neraca transaksi berjalan terhadap GDP pada grafik 1, maka Indonesia telah mengalami defisit neraca transaksi berjalan sebanyak dua belas kuartal pasca krisis ekonomi 1997. Di antaranya, pada tahun 2004 kuartal I, defisit neraca transaksi berjalan terjadi karena adanya peningkatan kegiatan impor minyak yang disertai dengan 
kenaikan harga minyak domestik (Neraca Pembayaran Indonesia, 2004). Pada tahun 2005, Indonesia kembali mengalami defisit neraca transaksi berjalan di kuartal III. Hal ini disebabkan oleh tingginya akselarasi pertumbuhan impor non migas (bahan baku dan barang modal) karena adanya kenaikan permintaan domestik (Laporan BI kepada DPR Triwulan III, 2005). Baru beberapa selang waktu pemulihan, neraca transaksi berjalan kembali mengalami defisit di kuartal II tahun 2008. Defisit terjadi karena adanya penurunan yang signifikan pada neraca perdagangan. Tak pelak, defisit ini terus berlanjut hingga kuartal III dan IV tahun 2008. Terpuruknya neraca transaksi berjalan tersebut disebabkan oleh adanya krisis global di Amerika Serikat yang berakibat pada ketidakpastian global (Neraca Pembayaran Indonesia Triwulan I-IV, 2008).

Neraca transaksi berjalan Indonesia kemudian mengalami defisit di kuartal IV tahun 2011. Defisit neraca transaksi berjalan tersebut belum pulih hingga sepanjang tahun 2012. Lesunya kinerja ekspor karena turunnya permintaan global menjadi pendorong adanya defisit tersebut. Bank Indonesia memprediksi defisit neraca transaksi berjalan kuartal II tahun 2013 bernilai US\$9 miliar. Akan tetapi, prediksi ini meleset karena defisit neraca transaksi berjalan di kuartal II tahun 2013 menembus hingga US\$9,8 miliar.

Melesetnya prediksi BI tersebut disebabkan karena kinerja ekspor ternyata tumbuh lebih rendah dibandingkan dengan perkiraan sebelumnya. Hal tersebut dibuktikan dengan semakin menurunnya ekspor jasa transportasi penumpang akibat banyaknya wisatawan nasional yang berlibur ke luar negeri dan meningkatnya jasa transportasi barang karena adanya peningkatan aktivitas impor (Neraca Pembayaran Indonesia, 2012-2013). Selain itu, impor Indonesia terutama minyak dan gas belum mengalami penurunan yang signifikan, meskipun harga Bahan Bakar Minyak (BBM) bersubsidi telah dinaikkan (Neraca online, 2013). Kondisi ini tercemin dalam tabel sebagai berikut:

\begin{tabular}{|c|c|c|c|c|c|c|c|c|c|c|}
\hline \multicolumn{11}{|c|}{$\begin{array}{c}\text { Tabel } 1 \\
\text { Neraca Transaksi Berjalan Indonesia Periode 2011Q1-2013Q2 (Dalam Juta Dollar) }\end{array}$} \\
\hline \multirow{2}{*}{ Keterangan } & \multicolumn{4}{|c|}{2011} & \multicolumn{4}{|c|}{2012} & \multicolumn{2}{|c|}{2013} \\
\hline & Q1 & Q2 & Q3 & Q4 & Q1 & Q2 & Q3 & Q4 & Q1 & Q2 \\
\hline Transaksi Berjalan & 2.947 & 273 & 766 & -2.301 & -3.105 & -7.979 & -5.336 & -7.763 & -5.819 & -9.848 \\
\hline A. Barang & 9.264 & 9.223 & 9.700 & 6.596 & 3.810 & 818 & 3.198 & 591 & 1.602 & -601 \\
\hline - Ekspor & 45.901 & 51.810 & 52.376 & 50.701 & 48.353 & 47.538 & 45.549 & 46.706 & 45.231 & 45.670 \\
\hline - Impor & -36.637 & -42.587 & -42.676 & -44.105 & -44.543 & -46.720 & -42.351 & -46.115 & -43.629 & -46.272 \\
\hline 1. Nonmigas & 8.899 & 10.622 & 9.291 & 6.621 & 4.694 & 1.974 & 3.968 & 2.899 & 4.457 & 1.662 \\
\hline a. Ekspor & 37.092 & 42.307 & 42.168 & 41.153 & 38.572 & 38.433 & 37.418 & 38.151 & 36.758 & 37.757 \\
\hline b. Impor & -28.193 & -31.685 & -32.877 & -34.532 & -33.878 & -36.460 & -33.450 & -35.252 & -32.301 & -36.095 \\
\hline 2. Minyak & -3.214 & -5.751 & -4.312 & -4.249 & -5.278 & -5.331 & -4.213 & -5.493 & -6.356 & -5.262 \\
\hline a. Ekspor & 4.855 & 4.845 & 4.929 & 4.947 & 4.592 & 4.332 & 4.222 & 4.744 & 4.298 & 4.243 \\
\hline b. Impor & -8.069 & -10.596 & -9.242 & -9.196 & -9.870 & -9.664 & -8.435 & -10.237 & -10.654 & -9.505 \\
\hline 3. Gas & 3.579 & 4.352 & 4.721 & 4.224 & 4.394 & 4.176 & 3.443 & 3.185 & 3.501 & 2.998 \\
\hline a. Ekspor & 12.968 & 4.658 & 5.278 & 4.601 & 5.189 & 4.772 & 3.909 & 3.810 & 4.175 & 3.670 \\
\hline b. Impor & -375 & -306 & -557 & -377 & -795 & -597 & -466 & -625 & -674 & -672 \\
\hline
\end{tabular}




\begin{tabular}{|c|c|c|c|c|c|c|c|c|c|c|}
\hline \multicolumn{11}{|c|}{$\begin{array}{c}\text { Tabel } 1 \\
\text { Neraca Transaksi Berjalan Indonesia Periode 2011Q1-2013Q2 (Dalam Juta Dollar) Lanjutan }\end{array}$} \\
\hline \multirow{2}{*}{ Keterangan } & \multicolumn{4}{|c|}{2011} & \multicolumn{4}{|c|}{2012} & \multicolumn{2}{|c|}{2013} \\
\hline & Q1 & Q2 & Q3 & Q4 & Q1 & Q2 & Q3 & Q4 & Q1 & Q2 \\
\hline B. Jasa - jasa & -1.822 & -3.133 & -2.562 & -3.115 & -2.075 & -2.893 & -2.480 & -3.322 & -2480 & -3.070 \\
\hline 1. Ekspor & 4.482 & 4.528 & 5.389 & 6.292 & 5.834 & 5.734 & 5.465 & 6.062 & 5.621 & 5.627 \\
\hline 2. Impor & -6.304 & -7.661 & -7.951 & -9.407 & -7.817 & -8.543 & -7.824 & -9.260 & -8.101 & -8.696 \\
\hline C. Pendapatan & -5.525 & -6.776 & -7.416 & -6.959 & -5.898 & -6.801 & -6.915 & -6.225 & -6.044 & -7.140 \\
\hline 1. Penerimaan & 580 & 637 & 659 & 641 & 767 & 652 & 583 & 625 & 922 & 612 \\
\hline 2. Pembayaran & -6.105 & -7.412 & -8.075 & -7.600 & -6.815 & -7.753 & -7.538 & -7.268 & -6.965 & -7.751 \\
\hline D. Transferberjalan & 1.029 & 960 & 1.045 & 1.176 & 1.058 & 898 & 861 & 1.193 & 1.102 & 962 \\
\hline 1. Penerimaan & 1.830 & 1.841 & 1.908 & 2.057 & 1.936 & 1.882 & 1.964 & 2.220 & 2.035 & 2.009 \\
\hline 2. Pembayaran & -800 & -881 & -863 & -881 & -879 & -984 & -1.102 & -1.007 & -934 & -1.047 \\
\hline
\end{tabular}

Berdasarkan tabel 1, neraca perdagangan barang pada komoditas minyak telah mengalami defisit dengan trend yang semakin meningkat selama periode 2011-2013. Akan tetapi, akibat besarnya jumlah ekspor pada komoditas nonmigas dan gas, maka defisit pada neraca perdagangan masih dapat diatasi. Namun, ketika terjadi penurunan aktivitas ekspor pada komoditas gas, defisit neraca perdagangan barang pada tahun 2013 kuartal II pun tak dapat dihindari.

Bank Pembangunan Asia (ADB/Asian Development Bank) juga memperkirakan neraca transaksi berjalan Indonesia akan berlangsung sepanjang 2014. Deputy Country Director Indonesia Resident Mission ADB, Edimon Ginting, melihat defisit neraca transaksi berjalan ini terjadi karena kondisi perekonomian global yang masih mengalami pelemahan (Kabar Bisnis, 2013). Apabila defisit neraca transaksi berjalan ini terus berlanjut dan tidak ada intervensi dari pemerintah, maka dikhawatirkan akan membawa pada krisis, seperti yang terjadi di Chili dan Meksiko (awal tahun 1980), United Kingdom dan Nordic (akhir tahun 1980), Meksiko dan Argentina (pertengahan tahun 1990), negara-negara di Asia Timur (akhir tahun 1990), dan Turki (awal tahun 1994 dan awal tahun 2001). Oleh karenanya, banyak negara menginginkan agar defisit neraca transaksi berjalannya tidak persisten (mean-reverting), karena apabila suatu negara mengalami defisit yang persisten, maka akan tercipta rebalancing, di mana negara tersebut secara terus-menerus melakukan impor sedangkan negara lainnya yang memasok kebutuhan impornya. Tentu, hal ini akan menyebabkan ketidakmerataan pada kesejahteraan masyarakat dunia. Selain menginginkan agar defisit neraca transaksi berjalannya tidak persisten, banyak negara juga menginginkan agar neraca transaksi berjalannya dalam kondisi sustainable.

Mean-reverting merupakan kondisi di mana defisit neraca transaksi berjalan tidak berlangsung lama. Artinya, defisit tersebut lama-kelamaan akan kembali pada keseimbangan jangka panjang. Jika defisit tersebut tidak kembali menuju keseimbangan jangka panjang akibat adanya shock, maka peristiwa ini disebut random walk phenomena. Lau et. al (2006) menemukan bahwa neraca transaksi berjalan di negara Asia-5 (Indonesia, Korea, Malaysia, Filipina dan 
Thailand) pada periode 1976Q1-2001Q4 bersifat mean-reverting. Sedangkan sustainabilitas neraca transaksi berjalan mengacu pada willingness dan capability dalam membiayai berbagai macam kegiatan—seperti impor dan pembayaran bunga utang luar negeri-melalui aktivitas ekspor. Sehingga, neraca transaksi berjalan suatu negara dapat dikatakan sustainable apabila pendapatan dari ekspornya telah mampu membiayai kegiatan impor dan pembayaran kewajiban berupa bunga utang luar negeri. Atau dengan kata lain, sustainabilitas neraca transaksi berjalan suatu negara merupakan refleksi dari hubungan kointegrasi antara ekspor dan impor \& bunga utang luar negeri (impor plus). Artinya, ekspor dan impor plus telah bergerak secara bersamasama menuju pada titik keseimbangan jangka panjang, sehingga current account balance pun tercipta. Hal ini dapat terjadi karena adanya penerapan kebijakan ekonomi makro yang efektif dalam jangka panjang. Oleh karenanya, dapat disimpulkan bahwa defisit neraca transaksi berjalan hanya sebuah fenomena jangka pendek yang pada akhirnya akan kembali menuju keseimbangan jangka panjang (Perera dan Verma, 2008).

Pendekatan yang menjelaskan hubungan kointegrasi antara ekspor dan impor plus sering disebut intertemporal budget constraint (Husted, 1992)². Pendekatan ini memungkinkan suatu negara untuk meminjam dan meminjamkan dana ke pasar internasional dalam memaksimalkan kepuasan sepanjang waktu berdasarkan budget constraint, artinya jika suatu negara ingin mengajukan pinjaman luar negeri, maka negara tersebut harus mempertimbangkan kondisi sisa pinjamannya saat ini, di mana pinjaman bersih luar negeri dari suatu negara harus sama dengan present value dari keseluruhan current account di masa yang akan datang atau dengan kata lain, pinjaman tersebut harus sama nominalnya dengan current account di masa depan yang dinilai pada waktu sekarang.

Penelitian yang secara khusus membahas sustainabilitas neraca transaksi berjalan di Indonesia dengan model intertemporal budget constraint belum pernah ada, hanya saja Baharumshah, Lau dan Fountas (2002) pernah melakukan penelitian mengenai sustainabilitas defisit neraca transaksi berjalan di empat negara ASEAN, yakni Indonesia, Malaysia, Filipina dan Thailand. Hasilnya, seluruh negara kecuali Malaysia belum memiliki neraca transaksi berjalan yang sustainable. Alasannya, pada periode penelitian yaitu 1961-1999, telah terjadi krisis Asia yang melanda sebagian besar negara ASEAN. Krisis yang terjadi pada tahun 1997 dan 1998 menyebabkan lesunya perekonomian domestik di negara ASEAN tersebut, sehingga external imbalances pun tak dapat dihindari.

Sejalan dengan penelitian yang telah dilakukan sebelumnya, Rahman (2011) yang meneliti sustainabilitas neraca transaksi berjalan di negara Malaysia (1960-2007) dan Indonesia (1960-2008) juga menemukan bahwa neraca transaksi berjalan Indonesia masih dalam kondisi unsustainable hingga tahun 2008. Menurutnya, pasca krisis 1997/1998, Malaysia lebih dapat me-manage defisit neraca perdagangannya dibandingkan dengan Indonesia.

2 Penjelasan teknis tentangkonsep intertemporal budget constraint pinjaman ala Husted (1992) dapat dilihat pada bagian lampiran. 
Oleh karenanya, pada penelitian ini akan dibahas mengenai persistensi dan sustainabilitas neraca transaksi berjalan di Indonesia periode dimulainya defisit neraca transaksi berjalan 2004Q1 hingga kini 2014Q1. Persistensi neraca transaksi berjalan akan dijelaskan melalui unit root test, sedangkan sustainabilitas akan dijelaskan melalui pendekatan intertemporal budget constraint dengan mengidentifikasi hubungan kointegrasi antara ekspor dan impor plus-nya. Ada beberapa metode yang dapat digunakan untuk menerangkan hubungan kointegrasi tersebut. Di antaranya, metode Engle-Granger, Johansen, dan Autoregressive Distributed Lag (ARDL).

Metode Engle-Granger menjelaskan hubungan jangka panjang dengan mengestimasi residualnya. Jika residualnya stasioner, maka ekspor dan impor plus memiliki hubungan kointegrasi. Namun, sebelum residualnya diestimasi, variabel ekspor dan impor plus harus terlebih dahulu memiliki derajat stasioneritas yang sama. Stasioneritas dapat berbentuk level atau I(0) maupun first difference atau I(1). Sama seperti metode Engle-Granger, metode Johansen juga mengharuskan semua variabelnya stasioner pada tingkat yang sama sebelum dilakukan tes kointegrasi. Lain halnya dengan metode Autoregressive Distributed Lag (ARDL), metode ini memungkinkan terkointegrasinya sejumlah variabel yang memiliki derajat stasioneritas yang berbeda-beda, sehingga lebih efisien dalam melakukan pengujian. Selain itu, metode ARDL merupakan metode yang tidak hanya mampu menjelaskan hubungan jangka panjang, tetapi juga mampu memperhitungkan dinamika jangka pendek, serta sangat cocok digunakan pada sampel yang berukuran kecil. Metode ini pernah digunakan oleh Hassan et al. (2012) untuk menganalisis sustainabilitas transaksi berjalan pada negara Iran. Hasilnya, defisit neraca transaksi Iran dalam kondisi sustainable.

Jika ditemukan bahwa Indonesia memiliki defisit neraca transaksi berjalan yang tidak persisten dan neraca transaksi berjalan yang unsustainable, maka penelitian ini memberikan kejelasan/konfirmasi dari peneliti-peneliti sebelumnya. Harapannya, penelitian ini dapat menjawab tantangan ke depan mengenai kemampuan neraca transaksi berjalan Indonesia dalam menjaga keseimbangan eksternalnya di tengah-tengah ketidakpastian iklim ekonomi global.

Bagian kedua dari paper ini menyajikan teori dan studi literatur terkait. Bagian ketiga mengulas data dan metode pengolahan yang dilakukan. Sebagian penjelasan teknis dari model dan metodologi diuraikan pada bagian lampiran. Bagian keempat mengulas hasil pengolahan data dan analisisnya, sementara kesimpulan dan implikasi kebijakan diuraikan pada bagian kelima dan menjadi bagian penutup dari paper ini.

\section{TEORI}

\subsection{Persistensi Neraca Transaksi Berjalan}

Persistensi defisit neraca transaksi berjalan merupakan kondisi di mana defisit neraca transaksi berjalan berlangsung secara terus-menerus. Hal ini dapat ditunjukkan melalui persamaan berikut: 


$$
E\left(C A_{t}\right)=C A_{t-1}
$$

Persamaan (1) menjelaskan bahwa expected current account pada periode sekarang (t) merupakan cermin dari current account pada periode sebelumnya (t-1). Dalam peramalan tentu terdapat faktor random yang dapat berubah sewaktu-waktu. Faktor random ini yang disebut dengan error. Error/kesalahan dalam peramalan dapat dihitung dengan persamaan sebagai berikut:

$$
\begin{aligned}
& \varepsilon_{t}=C A_{t}-E\left(C A_{t}\right) \\
& \varepsilon_{t}=C A_{t}-C A_{t-1} \\
& C A_{t}=C A_{t-1}+\varepsilon_{t}
\end{aligned}
$$

Persamaan (4) menunjukkan fenomena random walk di mana nilai neraca transaksi berjalan pada waktu sekarang ( $\mathrm{t}$ ) sama dengan nilai neraca transaksi berjalan pada periode sebelumnya (t-1) ditambah random factor (Clower dan Ito, 2005).

\subsection{Sustainabilitas Neraca Transaksi Berjalan}

Dalam penelitian ini akan diaplikasikan model intertemporal budget constraint yang menjelaskan hubungan ekspor dan impor plus dalam keseimbangan jangka panjang (Husted, 1992). Untuk menyederhanakan pembahasan, asumsi yang harus dibangun adalah bahwa perekonomian bersifat terbuka dan memiliki ukuran yang relatif kecil, di mana hanya ada satu barang yang diproduksi dan diekspor. Juga diasumsikan bahwa tidak ada campur tangan pemerintah, dan negara dapat meminjam dari dan meminjamkan dana ke pasar internasional, dan suku bunga yang digunakan adalah suku bunga dunia. Asumsi terakhir yang digunakan adalah bahwa agen bersifat rasional dan memaksimalkan kepuasan sepanjang waktu dengan suatu kendala anggaran tertentu (budget constraint).

Persamaan budget constraint pada periode t adalah sebagai berikut:

$$
C_{t}=Y_{t}+B_{t}-I_{t}-\left(1+r_{t}\right) B_{t-1}
$$

di mana $C_{t}$ adalah konsumsi saat ini, $Y_{t}$ adalah pendapatan, $B_{t}$ adalah pinjaman bersih (utang-piutang), I adalah investasi, dan $\left(1+r_{t}\right) B_{t-1}$ adalah bunga pinjaman bersih dari periode sebelumnya. Seperti sudah diketahui bahwa dalam persamaan identitas $Y_{t}=C_{t}+I_{t}+X-M$, di mana $X-M$ merupakan Current Account (CA), atau $Y_{t}-C_{t}-I_{t}=X_{t}-M_{t}=C A_{t}$. Sehingga: 


$$
B_{t}=\sum_{i=1}^{\infty} \mu_{i} C A_{t+i}+\lim _{n \rightarrow \infty} \mu_{n} B_{t+n}
$$

$$
\text { di mana }{ }_{n \rightarrow \infty} \mu_{n} B_{t+n}=0
$$

Persamaan (6) memperlihatkan bahwa pinjaman bersih luar negeri $\left(B_{t}\right)$ di suatu perekonomian negara dalam periode t merupakan present value $\left(P V_{t}\right)$ dari keseluruhan current account di masa yang akan datang atau dengan kata lain, pinjaman tersebut harus sama nominalnya dengan current account di masa depan yang dinilai pada waktu sekarang. Jika $B_{t}>P V_{t}$ maka negara tersebut akan kembali berutang untuk membayar sisa utang luar negerinya. Namun, jika $B_{t}<P V_{t}$ maka negara kembali berutang untuk menambah investasi domestik, karena utang pada periode sebelumnya dirasakan banyak membawa manfaat.

Konsep intertemporal budget constraint di atas digunakan dalam menjelaskan keberlanjutan/sustainabilitas neraca transaksi berjalan yang tercermin melalui hubungan kointegrasi antara ekspor dan impor plus, ditunjukkan dengan persamaan berikut:

$$
X_{t}=\alpha+M M_{t}+\varepsilon t
$$

Persamaan (7) menunjukkan bahwa ekspor pada periode $t\left(X_{t}\right)$ memiliki hubungan kointegrasi dengan impor plus (impor yang ditambahkan dengan bunga yang harus dibayarkan) pada periode t. Artinya, jika ekspor dan impor plus terkointegrasi, maka keduanya akan bergerak secara bersama-sama menuju pada keseimbangan jangka panjang (Jain and Sami, 2012).

\subsection{Literatur Terdahulu}

Penelitian mengenai persistensi neraca transaksi berjalan masih jarang dilakukan. Lau et. al (2006) melakukan penelitian terhadap neraca transaksi berjalan di negara Asia-5 (Indonesia, Korea, Malaysia, Filipina dan Thailand) pada periode 1976Q1-2001Q4 dan ditemukan bahwa defisit neraca transaksi berjalan di negara Asia-5 bersifat mean-reverting/tidak persisten. Kontras dengan Lau et. al. (2006), Clower dan Ito (2012) menemukan bahwa defisit neraca transaksi berjalan di negara maju dan negara berkembang mengalami persistensi. Penelitian dilakukan di periode 1960Q1-2010Q4 pada 71 negara, termasuk Indonesia. Sedangkan penelitian mengenai sustainabilitas neraca transaksi berjalan melalui identifikasi hubungan kointegrasi antara ekspor dan impor plus telah banyak dilakukan di berbagai negara. Utkulu (1998) dan Celik (2011) melakukan penelitian sustainabilitas neraca transaksi berjalan di negara Turki. Konya (2009) meneliti hal serupa di negara Czech Republic, Hungaria, dan Slovenia. Lain halnya dengan Perera dan Verma (2008) yang menganalisis sustainabilitas neraca transaksi berjalan di negara Srilanka, Yin dan Hamori (2011) di negara China, serta Hassan et al. (2012) yang menganalisis sustainabilitas neraca transaksi berjalan di negara Iran. 
Seluruh peneliti melakukan identifikasi kointegrasi dalam menjelaskan hubungan ekspor dan impor plus dalam jangka panjang, hanya saja masing-masing peneliti memiliki modifikasi tersendiri dalam menganalisisnya. Utkulu (1998), dan Celik (2011) menggunakan metode EngleGrenger dalam menjelaskan hubungan ini. Metode Engle-Grenger menggunakan pendekatan teknik persamaan tunggal (single-equation approach) yang hanya memiliki satu hasil kointegrasi. Sedangkan Perera et al. (2008), Konya (2009), dan Baharumshah, Lau dan Fountas (2002) menganalisis sustainabilitas neraca transaksi berjalan dengan metode Johansen Test. Metode ini mengijinkan terdapat lebih dari satu hasil kointegrasi. Jika ada kointegrasi lebih dari satu, maka metode Engle-Granger menjadi misleading. Namun, dalam pengujian dengan Johasen Test terkadang memiliki hasil yang mengandung ambiguitas, karena berbedanya nilai Trace Statistic dan Max-Eigen dalam menunjukkan hubungan kointegrasi. Selain itu, kelemahan dari metode Engle-Granger dan Johansen adalah adanya persyaratan data series yang harus memiliki derajat stasioneritas yang sama, yakni pada level I(0) atau I(1) dan kedua metode tersebut belum memperhitungkan dinamika jangka pendek menuju keseimbangan jangka panjang. Lain halnya dengan Hassan et al. (2012) yang menganalisis sustainabilitas neraca transaksi berjalan melalui metode Autoregressive Distributed Lag (ARDL). Metode ARDL memungkinkan terkointegrasinya sejumlah variabel yang memiliki derajat stasioneritas yang berbeda-beda, sehingga lebih efisien dalam melakukan pengujian dan lebih konsisten dalam menunjukkan hubungan kointegrasi, karena adanya koefisien jangka panjang dan jangka pendek. Selain itu, ARDL sangatlah cocok dengan sampel yang kecil. Oleh karenanya, dalam penelitian ini akan digunakan metode ARDL yang merupakan stage of art dari penelitian-penelitian sebelumnya.

\section{METODOLOGI}

\subsection{Persistensi Neraca Transaksi Berjalan}

\section{1) Uji Unit Root Augmented Dickey Fuller (ADF)}

Uji ini bertujuan untuk melihat stasioneritas data yang akan digunakan untuk menguji persistensi neraca transaksi berjalan. Untuk memudahkan pemahaman mengenai unit root, perhatikan model berikut ini:

$$
C A_{t}=C A_{t-1}+\varepsilon_{t}
$$

Ubah persamaan (8) ke dalam persamaan ekonometrika empiris yang mengandung unit root sebagai berikut:

$$
C A_{t}=\beta_{1}+\rho C A_{t-1}+\varepsilon_{t}
$$

Jika $\rho=1$ maka model tersebut menjadi random walk tanpa trend. Dari sini lah muncul masalah pada varian $C A_{t^{\prime}}$ sehingga $C A_{t}$ memiliki data "unit root" atau tidak stasioner, dikarenakan 
data stasioner mempunyai nilai $\rho$ yang besarnya $-1<\rho<1$. Apabila persamaan (9) di atas dikurangi $C A_{t-1}$ pada sisi kanan dan kiri, maka persamaannya menjadi:

$$
\begin{gathered}
C A_{t}-C A_{t-1}=\beta_{1}+\rho C A_{t-1}-C A_{t-1}+\varepsilon_{t} \\
\Delta C A_{t}=\beta_{1}+(\rho-1) C A_{t-1}+\varepsilon_{t}
\end{gathered}
$$

Atau dapat ditulis dengan:

$$
\Delta C A_{t}=\beta_{1}+\emptyset C A_{t-1}+\varepsilon_{t}
$$

Jika menambahkan trend pada persamaan (10), maka bentuknya menjadi seperti berikut:

$$
\Delta C A_{t}=\beta_{1}+\beta_{2} t+\varnothing C A_{t-1}+\varepsilon_{t}
$$

Persamaan (11) mengasumsikan bahwa $\varepsilon_{t}$ tidak berkorelasi dengan dependen variabel. Untuk mengantisipasi adanya korelasi tersebut, Dickey Fuller mengembangkan pengujiannya dengan menambahkan lag pada dependen variabel. Tes ini dinamakan dengan Augmented Dickey Fuller (ADF), ditunjukan sebagai berikut:

$$
\Delta C A_{t}=\beta_{1}+\beta_{2} t+\varnothing C A_{\mathrm{t}-1}+\sum_{i=1}^{m} \propto_{i} \Delta C A_{t-i}+\varepsilon_{\mathrm{t}}
$$

Jika dijabarkan, maka formulasinya adalah,

$$
\Delta C A_{t}=\beta_{1}+\beta_{2} t+\varnothing C A_{t-1}+\propto_{1} \Delta C A_{t-1}+\propto_{2} \Delta C A_{t-2}+\ldots+\propto_{m} \Delta C A_{t-m}+\varepsilon_{\mathrm{t}}
$$

di mana $\Delta C A_{t-1}=\left(C A_{t-1}-C A_{t-2}\right)$. Dari persamaan di atas dapat dibuat hipotesis sebagai berikut:

$$
H_{0}: \varnothing=0 \text { dan } H_{1}: \varnothing \neq 0
$$

Jika hipotesis $\emptyset=0$ tidak dapat ditolak, maka $\rho=0$, artinya data $C A_{t}$ mengandung unit root atau tidak stasioner. Namun jika hipotesis tersebut dapat ditolak, maka dapat diartikan bahwa data $C A_{t}$ tidak mengandung unit root atau stasioner. Di terima atau ditolaknya suatu hipotesis perlu dilakukan pengujian secara individu melalui uji t sebagai berikut:

$$
t=\frac{\widehat{\emptyset}}{s e(\widehat{\varnothing})}
$$

$\widehat{\emptyset}$ Merupakan estimasi terhadap $\emptyset$ dan $(\widehat{\varnothing})$ merupakan standar deviasi sampling dari hasil estimasi (standard error). Jika nilai t-statistik lebih besar dibandingan dengan critical value, maka dapat disimpulkan bahwa data tidak mengandung unit root atau stasioner (vice versa). 


\section{2) Philips-Perron Test}

Gujarati (2003) menyatakan bahwa Philips dan Perron dapat mengantisipasi adanya serial korelasi pada error term tanpa harus menambahkan lag difference terms, seperti yang telah dilakukan sebelumnya pada persamaan (12). Tes ini hanya melakukan pengetatan pada uji t untuk meningkatkan power dari kestasioneritasan data. Hal ini dapat diilustrasikan sebagai berikut:

$$
\Delta C A_{t}=\beta_{1}+\emptyset C A_{t-1}+\varepsilon_{t}
$$

Jika menambahkan trend pada persamaan (14), maka bentuknya menjadi seperti berikut:

$$
\Delta C A_{t}=\beta_{1}+\beta_{2} t+\varnothing C A_{t-1}+\varepsilon_{t}
$$

Dalam ADF koefisien $\emptyset$ diuji dengan t pada persamaan (15), sedangkan dalam PhilipsPerron koefisien $\emptyset$ diuji dengan t sebagai berikut:

$$
\tilde{t}=t\left(\frac{\gamma_{0}}{f_{0}}\right)^{1 / 2}-\frac{T\left(f_{0}-\gamma_{0}\right)(\operatorname{se}(\widehat{\varnothing}))}{2 f_{0}{ }^{1 / 2} s}
$$

di mana $\gamma_{0}=(T-k) s^{2} / T$. $\gamma_{0}$ merupakan consistent estimate, $T$ jumlah observasi, $k$ jumlah regressor dan s standar error pada regresi. $f_{0}$ merupakan estimator dari spektrum residual pada frekuensi zero. $f_{0}$ yang digunakan pada penelitian ini berdasarkan Bartlett Kernel dengan Newey-West sebagai optimal Bandwidth-nya, dan pilihan $f_{0}$ sudah tersedia pada aplikasi Eview 6.0 (Eviews 6 Users Guide). Keunggulan lain dari uji ini adalah kemampuannya untuk dapat menangkap adanya structural breaks yang terjadi pada sebagian besar data makroekonomi (Enders, 2004).

\subsection{Sustainabilitas Neraca Transaksi Berjalan}

Berdasakan Pesaran et al. (2001), model ARDL merupakan model Vector Autoregression (VAR) dari order $p$, dinotasikan dengan $\operatorname{VAR}(p)$, yang fungsinya sebagai berikut:

$$
z_{t}=\mu+\propto t+\sum_{i=1}^{p} \lambda_{i} z_{t-i}+\varepsilon_{t}
$$

dimana $z_{t}$ adalah vector dari $X_{t}$ dan $M M_{t}$; konstanta $\mu=\left[\mu_{x}, \mu_{M M}\right]$; dan $\lambda_{i}$ merupakan matrix dari parameter VAR pada lag $i$. Berdasarkan persamaan (16), maka dapat dikembangkan model Vector Error Correction Model (VECM) sebagai berikut: 


$$
z_{t}=\mu+\propto t+\lambda z_{t-1}+\sum_{i=1}^{p-1} \gamma_{i} \Delta z_{t-i}+\varepsilon_{t}
$$

Mengikuti Pesaran et al. (2001), $X_{t}$ harus dalam bentuk variabel first difference atau I(1), sedangkan regressor dapat berupa level I(0) atau first difference I(1), sehingga model penelitian ini adalah sebagai berikut:

$$
\begin{aligned}
& \Delta X_{t}=\propto_{0}+\beta_{1} X_{t-1}+\beta_{2} M M_{t-1}+\sum_{i=1}^{p} \beta_{3} \Delta X_{t-i}+\sum_{i=0}^{q} \beta_{4} \Delta M M_{t-i}+u_{t} \\
& \Delta X_{t}=\propto_{0}+\propto_{1} t+\beta_{1} X_{t-1}+\beta_{2} M M_{t-1}+\sum_{i=1}^{p} \beta_{3} \Delta X_{t-i}+\sum_{i=0}^{q} \beta_{4} \Delta M M_{t-i}+u_{t}
\end{aligned}
$$

Koefisien merepresentasikan dinamika jangka panjang dari model, sedangkan koefisien merepresentasikan hubungan jangka pendek dari model tersebut. Dari persamaan di atas, dapat dibuat hipotesis sebagai berikut:

$$
\begin{aligned}
& H_{0}: \beta_{1}=0 \text { dan } \beta_{2}=0 \\
& H_{1}: \beta_{1} \neq 0 \text { atau } \beta_{2} \neq 0
\end{aligned}
$$

Jika hipotesis tidak dapat ditolak, maka dapat diartikan bahwa tidak terdapat hubungan antara ekspor dan impor plus dalam jangka panjang. Sedangkan apabila hipotesis tersebut dapat ditolak, maka dapat diartikan bahwa terdapat hubungan jangka panjang di antara variabel ekspor dan impor plus. Hipotesis mana yang terpenuhi akan bergantung pada hasil akhir pengujian $\mathrm{F}$ statistik yang dibandingkan dengan nilai-nilai kritis yang ditampilkan dalam tabel Cl (iii) dan Cl (v) dalam Pesaran et al. (2001). Mengacu pada Pesaran dan Pesaran (2001) tersebut, nilai kritis batas terbawah (lower bound critical value) mengasumsikan bahwa variabel independen terkointegrasi pada ordo nol atau I(0). Sementara nilai kritis batas teratas (upper bound critical value) mengasumsikan bahwa variabel independen terkointegrasi pada ordo satu atau I(1). Oleh karena itu, F statistik yang lebih besar daripada nilai kritis (baik pada lower maupun upper) menyimpulkan bahwa terdapat hubungan jangka panjang antara ekpor dan impor plus-nya. Namun, jika F statistik yang didapat nilainya di antara lower dan upper, maka hasilnya tidak dapat disimpulkan (Fuso dan Magnus, 2006).

\section{HASIL DAN ANALISIS}

\subsection{Persistensi Neraca Transaksi Berjalan}

Seperti telah dijelaskan sebelumnya bahwa persistensi defisit neraca transaksi berjalan dapat digambarkan melalui fenomena random walk, di mana defisit saat ini sangat dipengaruhi 
oleh defisit pada waktu sebelumnya dan random factorlerror term. Fenomena ini dapat ditangkap melalui uji stasioneritas Augmented Dickey Fuller (ADF) dan Philip-Perron. Neraca transaksi berjalan yang mengikuti pola random walk akan menghasilkan data yang tidak stasioner atau mengandung unit root. Ketidakstasioneran inilah yang disebut dengan persistensi. Sebaliknya, neraca transaksi berjalan yang tidak mengikuti pola random walk atau yang biasa disebut mean-reverting akan menghasilkan data yang stasioner. Data yang stasioner tersebut memiliki probabilitas untuk dapat dikontrol kestabilannya jika sewaktu-waktu terkena shock, sehingga tidak menyebabkan permanent impact atau persistent (Lau et. al., 2006). Uji stasioneritas ADF dan Philip-Perron neraca transaksi berjalan Indonesia periode 2004Q1-2014Q1 dapat ditunjukkan pada tabel sebagai berikut:

\begin{tabular}{|c|c|c|c|c|}
\hline \multicolumn{5}{|c|}{$\begin{array}{c}\text { Tabel } 2 \\
\text { Uji Stasioneritas Neraca Transaksi Berjalan Periode 2004Q1-2014Q1 }\end{array}$} \\
\hline \multirow[b]{2}{*}{ Periode } & \multicolumn{2}{|c|}{ ADF Test } & \multicolumn{2}{|c|}{ PP Test } \\
\hline & $\begin{array}{l}\text { Dengan } \\
\text { Intersep }\end{array}$ & $\begin{array}{l}\text { Dengan Intersep } \\
\text { dan tren }\end{array}$ & $\begin{array}{l}\text { Dengan } \\
\text { Intersep }\end{array}$ & $\begin{array}{l}\text { Dengan Intersep } \\
\text { dan tren }\end{array}$ \\
\hline \multirow[t]{2}{*}{ 2004Q1-2014Q1 } & $-1,7769$ & $-3,0130$ & $-1,7769$ & $-3,0130$ \\
\hline & {$[0,3862]$} & {$[0,1414]$} & {$[0,3862]$} & {$[0,1414]$} \\
\hline
\end{tabular}

\begin{tabular}{|c|c|c|c|c|}
\hline \multicolumn{5}{|c|}{$\begin{array}{c}\text { Tabel } 3 \\
\text { Uji Stasioneritas Neraca Transaksi Berjalan Periode 2004Q1-2014Q1 dengan sensitivity test }\end{array}$} \\
\hline \multirow[b]{2}{*}{ Periode } & \multicolumn{2}{|c|}{ ADF Test } & \multicolumn{2}{|c|}{ PP Test } \\
\hline & $\begin{array}{l}\text { Dengan } \\
\text { Intersep }\end{array}$ & $\begin{array}{l}\text { Dengan Intersep } \\
\text { dan tren }\end{array}$ & $\begin{array}{l}\text { Dengan } \\
\text { Intersep }\end{array}$ & $\begin{array}{l}\text { Dengan Intersep } \\
\text { dan tren }\end{array}$ \\
\hline \multirow[t]{2}{*}{ 2004Q1-2007Q4 } & $-3,4565^{\star *}$ & $-3,7928^{* * *}$ & $3,439^{* *}$ & $3,7701^{\text {** }}$ \\
\hline & {$[0,0254]$} & {$[0,0474]$} & {$[0,0262]$} & {$[0,0492]$} \\
\hline \multirow[t]{2}{*}{ 2008Q1-2014Q1 } & $-1,5642$ & $-2,1743$ & $-1,5445$ & $-2,2194$ \\
\hline & {$[0,4848]$} & {$[0,4814]$} & {$[0,4945]$} & {$[0,4584]$} \\
\hline \multicolumn{5}{|c|}{$\begin{array}{l}*{ }^{* *}, * * \text { Signifikan pada } \alpha=1 \%, 5 \%, \text { dan } 10 \% \\
\text { Sumber: Hasil Pengolahan Data }\end{array}$} \\
\hline \multirow[b]{2}{*}{ Periode } & \multicolumn{2}{|c|}{ ADF Test } & \multicolumn{2}{|c|}{ PP Test } \\
\hline & $\begin{array}{l}\text { Dengan } \\
\text { Intersep }\end{array}$ & $\begin{array}{l}\text { Dengan Intersep } \\
\text { dan tren }\end{array}$ & $\begin{array}{l}\text { Dengan } \\
\text { Intersep }\end{array}$ & $\begin{array}{l}\text { Dengan Intersep } \\
\text { dan tren }\end{array}$ \\
\hline \multirow[t]{2}{*}{ 2004Q1-2009Q4 } & $-3,6348^{* *}$ & $-3,5637^{* * *}$ & $-3,6348^{* * *}$ & $-3,5637^{* * *}$ \\
\hline & {$[0,0130]$} & {$[0,0559]$} & {$[0,0130]$} & {$[0,0559]$} \\
\hline \multirow[t]{2}{*}{ 2010Q1-2014Q1 } & $-1,4923$ & $-1,8649$ & $-1,4428$ & $-1,9805$ \\
\hline & {$[0,5115]$} & {$[0,6254]$} & {$[0,5354]$} & {$[0,5674]$} \\
\hline
\end{tabular}




\begin{tabular}{|c|c|c|c|c|}
\hline \multirow[b]{2}{*}{ Periode } & \multicolumn{2}{|c|}{ ADF Test } & \multicolumn{2}{|c|}{ PP Test } \\
\hline & $\begin{array}{l}\text { Dengan } \\
\text { Intersep }\end{array}$ & $\begin{array}{l}\text { Dengan Intersep } \\
\text { dan tren }\end{array}$ & $\begin{array}{l}\text { Dengan } \\
\text { Intersep }\end{array}$ & $\begin{array}{l}\text { Dengan Intersep } \\
\text { dan tren }\end{array}$ \\
\hline \multirow[t]{2}{*}{ 2004Q1-2010Q4 } & $-4,2079^{* *}$ & $-3,9927^{\star *}$ & $-4,2079^{* *}$ & $-3,9927^{* *}$ \\
\hline & {$[0,0030]$} & {$[0,0215]$} & {$[0,0030]$} & {$[0,0215]$} \\
\hline \multirow[t]{2}{*}{ 2011Q1-2014Q1 } & $-2,2039$ & $-1,4985$ & $-2,2681$ & $-1,2926$ \\
\hline & {$[0,2142]$} & {$[0,7708]$} & {$[0,1955]$} & {$[0,8372]$} \\
\hline
\end{tabular}

* ${ }^{* *}, * * *$ Signifikan pada $\alpha=1 \%, 5 \%$, dan $10 \%$

Sumber: Hasil Pengolahan Data

Berdasarkan pengujian stasioneritas di atas, maka dapat disimpulkan bahwa Indonesia mengalami defisit neraca transaksi berjalan karena adanya global imbalances yang masuk ke dalam perekonomian domestik, terbukti dari adanya pola yang terbentuk berdasarkan pengujian stasioneritas sebagai berikut:

\begin{tabular}{l|l|l}
\multicolumn{1}{c}{ Tabel 4 } \\
\multicolumn{1}{c}{ Periode } & \multicolumn{1}{c}{ Rangkuman Uji Stasioneritas } \\
\hline 2004Q1-2007Q4 & \multicolumn{1}{c}{ Hasil Tes Stasioneritas } & \multicolumn{1}{c}{ Kesimpulan } \\
\hline 2008Q1-2014Q1 & Stasioner & Tidak Persisten \\
\hline 2004Q1-2009Q4 & Tidak Stasioner & Persisten \\
\hline 2010 Q1-2014Q1 & Stasioner & Tidak Persisten \\
\hline 2004Q1-2010Q4 & Tidak Stasioner & Persisten \\
\hline 2011Q1-2014Q1 & Stasioner & Tidak Persisten \\
\hline
\end{tabular}

Global imbalances bermula dari krisis yang dialami Amerika Serikat (AS) di tahun 2008. Sebagai salah satu negara adidaya, tentu krisis ini tidak hanya mempengaruhi kondisi perekonomian Amerika, tetapi juga perekonomian di negara lain, termasuk Indonesia. Pengaruh krisis tersebut ditransmisikan melalui dua jalur, yakni jalur finansial dan jalur perdagangan. Dari jalur finansial, institusi atau lembaga keuangan yang memiliki aset pada perusahaan yang bermasalah akan secara langsung terkena dampaknya. Selain itu, akibat adanya krisis ini, banyak perusahaan asing yang menarik dananya dari Indonesia di pasar saham, karena mengalami kesulitan likuiditas di negaranya. Dari jalur perdagangan, permintaan impor Amerika dari Indonesia mengalami penurunan karena lesunya daya beli masyarakat Amerika akibat krisis tersebut (Listiarso, 2013).

Krisis yang dialami oleh Amerika terjadi karena adanya kredit macet perumahan bagi kalangan subprime sejak tahun 2007. Puncaknya, lembaga keuangan besar penyedia kreditLehman Brothers - mengalami kebangkrutan di tahun 2008, yang kemudian memberikan efek domino ke seluruh dunia, salah satunya Indonesia. Hal tersebut yang menyebabkan defisit neraca transaksi berjalan Indonesia di tahun 2008. Namun defisit neraca transaksi berjalan di 
tahun tersebut tidak mengalami kondisi yang persisten, karena adanya pemulihan di tahun 2009 (Outlook Ekonomi Indonesia, 2009).

Di tahun 2009, perekonomian Amerika menunjukkan performa yang kian membaik sebagai refleksi dari efektifnya kebijakan paket penyelamatan ekonomi sebesar USD838 miliar yang dibuat oleh pemerintah dan Bank Sentral AS. Pemulihan kondisi perekonomian AS ini berimplikasi pada semakin meningkatnya arus investasi ke pasar modal domestik dan meningkatnya permintaan impor Amerika dari Indonesia. Sehingga, neraca transaksi berjalan kembali surplus di tahun 2009 hingga kuartal III tahun 2011 (Neraca Pembayaran Indonesia Triwulan IV, 2011).

Baru beberapa selang waktu pemulihan, Indonesia kembali terkena dampak krisis Eropa di akhir tahun 2011. Sama seperti krisis AS, transmisi pengaruh krisis Eropa dirasakan oleh Indonesia melalui dua jalur, yakni jalur perdagangan dan jalur finansial. Untuk jalur perdagangan, lemahnya daya beli masyarakat Eropa akan menurunkan permintaan barang, sehingga ekspor Indonesia pun juga akan turun. Sedangkan dampak yang dirasakan melalui jalur finansial adalah adanya ketidakpercayaan investor global yang menanamkan modalnya di negara-negara Eropa akibat rasio utang yang besar terhadap PDB di negara tersebut, menyebabkan investor global mencari tempat-tempat yang aman untuk menaruh dananya. Indonesia termasuk sebagai salah satu negara yang menjadi tujuan investasi para investor global tersebut. Investasi yang banyak ditanamkan berupa investasi portofolio. Derasnya arus modal ini menyebabkan penguatan mata uang rupiah, karena banyaknya dolar yang masuk ke Indonesia. Penguatan rupiah ini menyebabkan penurunan ekspor akibat harga komoditas domestik yang dinilai mahal oleh pasar luar negeri. Ini yang menyebabkan neraca transaksi berjalan Indonesia mengalami persistensi defisit hingga kuartal I tahun 2014.

\subsection{Sustainabilitas Neraca Transaksi Berjalan}

Prosedur awal yang dilakukan dalam metode Autoregressive Distributed Lag (ARDL) adalah menentukan lag optimal menggunakan Schwarz Information Criterion (SIC). Berdasarkan SIC, lag optimal yang dapat digunakan dalam penelitian ini adalah lag 1. Namun, Pindyck dan Rubinfeld (1991) menyarankan untuk melakukan run pada model dengan beberapa lag yang berbeda dan memastikan bahwa hasil yang didapat tidak sensitif terhadap panjangnya lag. Sehingga, pada penelitian ini digunakan 4 lag untuk menguji sensitivitas hasil tersebut. Setelah mendapatkan lag yang optimal, maka uji kointegrasi Autoregressive Distributed Lag (ARDL) dapat dilakukan. Hasilnya adalah sebagai berikut: 


\begin{tabular}{|c|c|c|c|c|c|}
\hline \multicolumn{6}{|c|}{$\begin{array}{c}\text { Tabel } 5 \\
\text { Uji Autoregressive Distributed Lag }\end{array}$} \\
\hline Komponen & Lag & $\mathbf{F}_{\mathrm{III}}$ & Kesimpulan & $\mathbf{F}_{\mathbf{V}}$ & Kesimpulan \\
\hline \multirow[t]{4}{*}{ Barang dan Jasa } & $1^{*}$ & 2,08 & Tidak terkointegrasi & 6,97 & Inconclusive \\
\hline & 2 & 1,13 & Tidak terkointegrasi & 5,82 & Inconclusive \\
\hline & 3 & 0,56 & Tidak terkointegrasi & 2,91 & Tidak terkointegrasi \\
\hline & 4 & 1,57 & Tidak terkointegrasi & 4,98 & Tidak terkointegrasi \\
\hline \multirow[t]{4}{*}{ Barang } & $1^{*}$ & 2,58 & Tidak terkointegrasi & 5,92 & Inconclusive \\
\hline & 2 & 1,79 & Tidak terkointegrasi & 5,45 & Tidak terkointegrasi \\
\hline & 3 & 0,90 & Tidak terkointegrasi & 2,62 & Tidak terkointegrasi \\
\hline & 4 & 2,03 & Tidak terkointegrasi & 4,48 & Tidak terkointegrasi \\
\hline \multirow[t]{4}{*}{ Jasa } & $1^{*}$ & 1,06 & Tidak terkointegrasi & 2,31 & Tidak terkointegrasi \\
\hline & 2 & 0,58 & Tidak terkointegrasi & 2,42 & Tidak terkointegrasi \\
\hline & 3 & 0,38 & Tidak terkointegrasi & 1,10 & Tidak terkointegrasi \\
\hline & 4 & 1,04 & Tidak terkointegrasi & 4,00 & Tidak terkointegrasi \\
\hline
\end{tabular}

Berdasarkan pengujian bound testing pada tingkat I(0) dan first difference atau I(1), maka dapat disimpulkan bahwa ekspor dan impor plus tidak memiliki hubungan kointegrasi. Atau dengan kata lain, kedua variabel tersebut tidak memiliki keseimbangan bersama dalam jangka panjang. Tidak terdapatnya hubungan dalam jangka panjang antara ekspor dan impor plus mencerminkan neraca transaksi berjalan Indonesia berada dalam kondisi unsustainable, baik barang maupun jasa. Artinya, Indonesia tidak mampu membiayai impor dan bunga utang luar negerinya melalui aktivitas ekspor, sehingga tercipta defisit pada neraca transaksi berjalan. Kondisi unsustainable ini terjadi di 3 (tiga) tahun terakhir, yakni di tahun 2011 kuartal IV hingga tahun 2014 kuartal I. Lebih dalam lagi, kondisi unsustainable terjadi pada sektor jasa.

Jasa

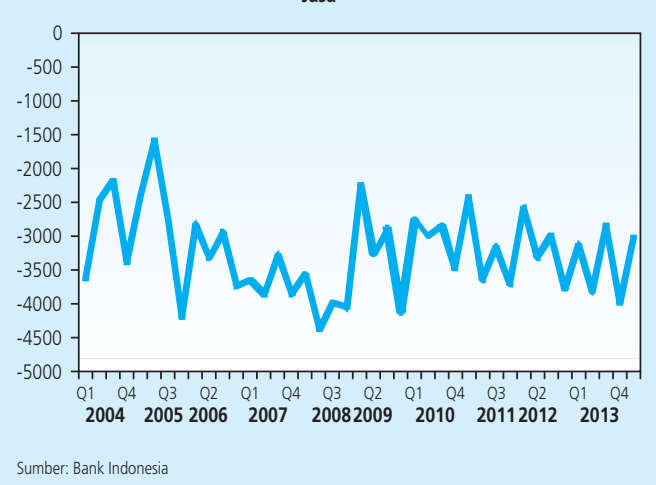

Defisit Neraca Jasa Indonesia Menurut Husted Periode 2004Q1-2014Q1 
Sektor jasa yang memiliki defisit terbesar adalah jasa transportasi, khususnya transportasi barang karena tingginya impor minyak domestik, terlihat pada grafik sebagai berikut:

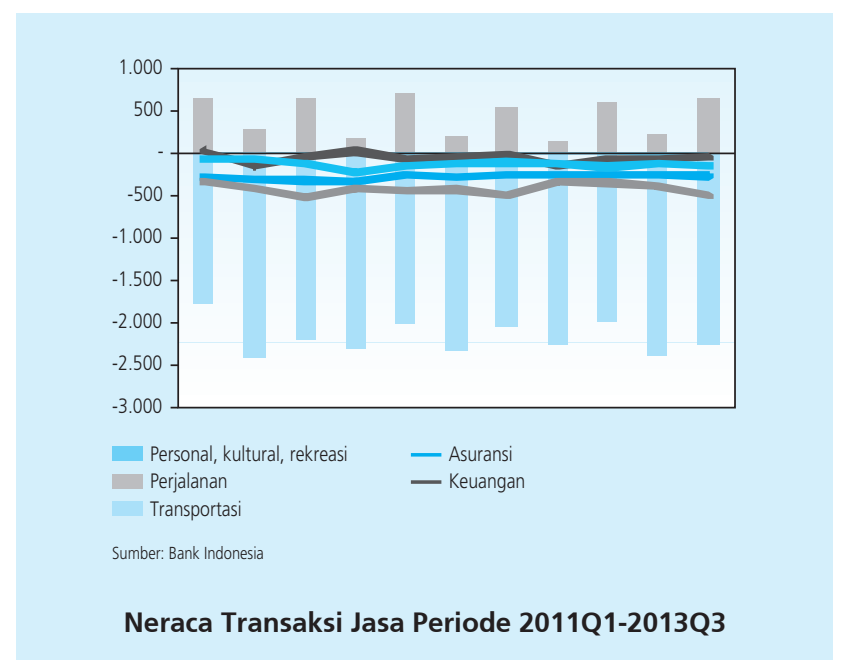

Bank Indonesia telah berupaya untuk menurunkan defisit pada neraca transaksi berjalan dengan tetap menjaga instrumen kebijakan utamanya, yakni BI Rate, karena jika BI Rate dinaikan, maka interest differential suku bunga domestik dan suku bunga luar negeri akan semakin melebar. Inilah yang akan mendorong investor asing untuk menanamkan modal ke dalam instrumen-instrumen keuangan di Indonesia, karena para investor tersebut akan mendapatkan tingkat pengembalian yang lebih tinggi, sehingga capital inflow meningkat. Namun, peningkatan capital inflow akan menambah pasokan dollar di Indonesia. Hal ini akan menyebabkan nilai tukar rupiah menguat/terapresiasi. Apresiasi nilai tukar rupiah mengakibatkan harga barang impor lebih murah dan barang ekspor di luar negeri menjadi lebih mahal atau kurang kompetitif, sehingga akan mendorong impor dan mengurangi ekspor. Turunnya ekspor menyebabkan berkurangnya produksi domestik, sehingga harga-harga barang akan meningkat dan pertumbuhan ekonomi pun akan melambat. Inilah fakta yang harus dihadapi di masa depan dan menjadi penyebab adanya fenomena kerentanan pada neraca transaksi berjalan. Hasil dari penelitian ini sejalan dengan dua peneliti sebelumnya, yakni Baharumshah, Lau \& Fountas (2002) dan Rahman (2011) yang menyatakan bahwa neraca transaksi berjalan Indonesia dalam kondisi unsustainable. Kondisi rentan terhadap guncangan tercipta karena adanya gejolak perekonomian dunia yang masuk ke pasar domestik (Baharumshah et. al. yang meneliti saat krisis Asia 1997/1998, Rahman yang meneliti saat krisis Amerika 2008, dan penelitian ini yang meneliti pasca krisis Eropa 2011). 


\section{KESIMPULAN}

Paper ini menguji persistensi dan sustainabilitas defisit neraca berjalan di Indonesia. Hasil pengujian menunjukkan defisit ini bersifat persisten pada selang periode 2011Q4-2014Q1, akibat pengaruh krisis Eropa yang terjadi pada kuartal empat 2011. Transmisi pengaruh krisis Eropa dirasakan oleh Indonesia melalui dua jalur, yakni jalur perdagangan dan jalur finansial. Dampak krisis pada jalur perdagangan tidak dirasakan secara langsung, karena Indonesia bukanlah negara mitra dagang utama bagi negara-negara di Eropa yang mengalami tekanan. Namun, transmisi melalui jalur finansial berupa derasnya arus investasi portofolio yang menyebabkan defisit neraca transaksi berjalan sebagai imbas adanya penguatan mata uang rupiah.

Kesimpulan kedua dari paper ini adalah bahwa neraca transaksi berjalan Indonesia berada dalam kondisi unsustainable. Kondisi unsustainable disebabkan karena adanya defisit neraca transaksi berjalan yang terjadi pada kuartal IV tahun 2011 hingga kuartal I tahun 2014. Defisit ini banyak disumbang oleh defisit yang terjadi pada neraca jasa, khususnya jasa transportasi karena besarnya impor minyak. Hasil dari penelitian ini sejalan dengan dua peneliti sebelumnya, yakni Baharumshah, Lau \& Fountas (2002) dan Rahman (2011) yang menyatakan bahwa neraca transaksi berjalan Indonesia dalam kondisi unsustainable. Kondisi rentan terhadap guncangan tercipta karena adanya gejolak perekonomian dunia yang masuk ke pasar domestik (Baharumshah et. al. yang meneliti saat krisis Asia 1997/1998, Rahman yang meneliti saat krisis Amerika 2008, dan penelitian ini yang meneliti pasca krisis Eropa 2011).

Mengacu pada hasil di atas maka perlu diupayakan optimalisasi empat paket kebijakan yang telah diluncurkan oleh pemerintah pada bulan Agustus 2013, terutama paket kebijakan yang dapat mendorong ekspor dalam mengatasi defisit neraca transaksi berjalan.Selain itu, perbaikan defisit neraca transaksi jasa, terutama jasa transportasi barang dengan penyediaan fasilitas transportasi yang memadai untuk kegiatan ekspor impor.

Penelitian ini hanya menggunakan periode 2004Q1 hingga 2014Q1 karena keterbatasan ketersediaan data. Oleh sebab itu, pada penelitian selanjutnya diharapkan menggunakan periode data yang lebih panjang agar dapat melihat tingkat persistensi dan sustainabilitas pada periode sebelum tahun 2004. Selain itu, perlu dibandingkan bagaimana kondisi tersebut jika dibandingkan dengan negara ASEAN lainnya. 


\section{DAFTAR PUSTAKA}

Arize, Augustine C. 2002. Import and Exports in 50 Countries Test of Cointegration and Structural Breaks. International Review of Economics and Finance, Vol. 11, pp 101-115.

Azgun, S. dan T. Ozdemir. 2008. Current Accounts Deficits Sustainability: Implications of Intertemporal Foreign Borrowing Constraint For Pakistan. Trakia Journal of Sciences, Vol. 6, No. 3, pp 3-9.

Baharumshah A. Z., Evan Lau dan Stilianos Fountas. 2002. On sustainability of current account deficits: Evidence from four ASEAN countries (National University of Ireland Working Paper No. 62)

Bank Indonesia. 2001-2013. Statistik Ekonomi Indonesia. Jakarta: BI.

Bank Indonesia. 2004-2013. Neraca Pembayaran Indonesia. Jakarta: BI.

Bank Indonesia. 2005. Laporan Bank Indonesia kepada DPR. Jakarta: BI.

Bank Indonesia. 2009. Outlook Ekonomi Indonesia 2009-2014. Jakarta: BI.

Binatli, Ayla Ogus dan Niloufer Sohrabji. 2012.Intertemporal Solvency ofTurkey's Current Account. Panoeconomicus, Vol. 1, pp 89-104.

Celik, Tuncay. 2011. Long Run Relationship between Export and Import: Evidence from Turkey for the period of 1990-2010. International Conference on Applied Economics.

Clower, Erica dan Hiro Ito. 2012. The Persistence of Current Account Balances and Its Determinants: The Implications for Global Rebalancing (ADB Institute Working Paper No. 200).

Djeutem, Edouard T. dan Pierre E. Nguimkeu. 2013. On the Sustainability of Current Account Deficits in Cameroon. International Journal of Economics and Financial Issues, Vol. 3, No. 2, pp 286-495.

Destaings, Nyongesa N., Mukras S. Mohamed dan Momanyi Gideon. 2013. Is Kenya Current Account Sustainable. European Scientific Journal, Vol. 9, No. 25, pp 171-190.

Enders. (2004). Applied Econometrics Time Series. New York: John Wiley Sons, Inc

Eviews 6 User's Guide II. 2007. Quantitative Micro Software. United States of America.

Falianty, Telisa A. 2003. Exchange Rate Overshooting: Sebuah Studi Empiris di Indonesia dalam sistem nilai tukar mengambang. Tesis pada Program Pascasarjana Ilmu Ekonomi Universitas Indonesia (tidak diterbitkan).

Ferretti, Milesi dan Assaf Razin. 1996. Persistent Current Account Deficits: A Warning Signal? International Journal Finance, Vol. 1, pp 161-181. 
Fuso, Oteng-Abayie Eric dan Frimpong Joseph Magnus. 2006. Bounds Testing Approach to Cointegration: An Examination of Foreign Direct Investment Trade and Growth Relationships. American Journal of Applied Sciences, Vol. 3 No. 11, pp 2079-2085.

Hassan H., Salih T.K dan Narmin D. 2012. Are Current Account Deficits Sustainable? New Evidence from Iran Using Bounds Testing Approach to Level Relationships. Economics The Open-Access Open-Assessment E-Journal.

Husted, Steven. 1992. The Emerging U.S Current Account Deficit in 1980s: A Cointegration Analysis. The Review of Economics and Statistics, Vol. 74, pp 159-166.

Iskandar. 2011. Analisis Hubungan Perkembangan Sektor Keuangan dan Pertumbuhan Ekonomi di Indonesia periode 1990:Q1-2009:Q4 pendekatan ARDL. Tesis pada Program Pascasarjana Ilmu Ekonomi Universitas Indonesia (tidak diterbitkan).

Ismayadi, Budi. 2009. Kointegrasi antara Investasi Langsung Luar Negeri, Perdagangan dan Pendapatan Perkapita di Indonesia 1976-2008 Pendekatan ARDL. Tesis pada Program Pascasarjana IImu Ekonomi Universitas Indonesia (tidak diterbitkan).

Jain, Vipin dan Janesh Sami. 2012. Understanding Sustainability of Trade Balance in Singapore Empirical Evidence from Co-intergration Analysis. View Point Journal, Vol. 2, No. 1, pp 3-9

Keong, C. C, Z. Yusop dan Venus Liew K. S. 2005. Export-Led Growth Hypothesis in Malaysia: An Investigation Using Bounds Test. Sunway Academic Journal, Vol. 2, pp 13-22.

Konya, Laszlo. 2008. The Sustainability of the Current Account in the Czech Republic, Hungaria and Slovenia. Empirical Economics Journal, Vol. 36, pp 367-384.

Krugman, Paul R. dan Maurice Obstfeld. 2003. International Economics Theory and Policy: Addison Wesley.

Lau, Evan, Ahmad Zubaidi Baharumshah dan Chan Tze Haw. 2006. Current Account: MeanReverting or Random Walk Behavior? Japan and The World Economy, Vol. 18, pp 90107.

Listiarso, Amiruli D. 2013. Pengaruh Karakteristik Krisis Finansial Global 2008 Terhadap Variabel Makroekonomi Indonesia: Analisis Pada Trade Dan Financial Channell. Tesis pada Program Pascasarjana Ilmu Ekonomi Universitas Indonesia (tidak diterbitkan).

Nachrowi, Nachrowi D. dan Hardius Usman. 2006. Pendekatan Populer dan Praktis Ekonometrika Untuk Analisis Ekonomi dan Keuangan. Jakarta: Lembaga Penerbit Fakultas Ekonomi UI.

Perera, N. dan R. Verma. 2008.An Empirical Analysis of Sustainability of Trade Deficit: Evidence from Sri Lanka. International Journal of Applied Econometrics and Quantitive Studies, Vol. 5, No. 1, pp 71-92. 
Pesaran, M. H. dan Bahram Pesaran. 1996. Working with Microfit 4.0: Interactive Econometric Analysis. Oxford: Oxford University Press.

Pesaran, M. H. dan Yongcheol Shin. 1997. An Autoregressive Distributed Lag Modelling Approach to Cointegration Analysis. A Revised Version of A Paper Presented atSymposium at the Centennial of Ragnar Frisch, The Norwegian Academy of Science and Letters, Oslo, March 3-5, 1995.

Pesaran, M. H., Y. Shin, dan R. J. Smith. 2001. BoundsTesting Approaches to the analysis of level relationships. Journal of Applied Econometrics, Vol. 16, pp 289-326.

Pyndick, R.S dan Daniel Rudenfeld. 1991. Econometric Models and Economic Forecasts Fourt Edition: McGraw-Hill International Edition.

Polat, Ozgur. (2011). Sustainability of Current Account Deficit in Turkey. African Journal of Business Management, Vol. 5, No. 2, pp 577-581.

Rahman, M. Z. 2011. Existence of Export-Import Cointegration: A Study on Indonesia and Malaysia. International Business Research, Vol. 4, No. 3, pp 108-115.

Romer, David. 2006. Advanced Macroeconomics Third Edition: McGraw-Hill International Edition.

Salomo, Ronny M. dan Pos M. Hutabarat. 2007. Peranan Perdagangan Internasional sebagai salah satu sumber pertumbuhan ekonomi Indonesia. Paper dipresentasikan pada seminar Parallel session IIID FEUI.

Trehan, Bharat dan Carl E. Walsh. 1991. Testing Intertemporal Budget Constraints: Theory and Application to U.S Federal Budget and Current Account. Journal of Money, Credit, and Banking, Vo. 23, No. 2, pp 206-223.

Utkulu, Utku. 1998. Are the Turkish External Deficits Sustainable? Evidence from the Cointegrating relationship between exports and imports. Dergisi, Vol. 13 No. 1, pp 119-132.

http://bisnis.liputan6.com/read/672922/4-paket-lengkap-kebijakan-ekonomi-pemerintah, 28 Agustus 2013.

www.kabarbisnis.com/read/2837033, 26 Februari 2013.

www.neraca.co.id/harian/article/31502/empatdefisitjadikendalaekonominasional, 5 Agustus 2013.

http://www.fiskal.kemenkeu.go.id/2010/Kliping/WartaFiskal/Edisi_3_2012/files/search/ searchtext.xml, Maret 2012.

Yin, Fengbao dan Shigeyuki Hamori. 2011. The Sustainability of Trade Balance in China. Economics Bulletin, Vol. 31, No. 3, pp 2090-2097. 


\section{LAMPIRAN}

\section{Konsep intertemporal budget constraint pinjaman (Husted, 1992)}

Persamaan budget constraint pada periode t adalah sebagai berikut:

$C_{t}=Y_{t}+B_{t}-I_{t}-\left(1+r_{t}\right) B_{t-1}$

di mana Ct adalah konsumsi saat ini, Yt adalah pendapatan, Bt adalah pinjaman bersih (hutang-piutang), It adalah investasi, dan $(1+\mathrm{rt})$ Bt-1 adalah pinjaman bersih dari periode sebelumnya.

Seperti sudah diketahui bahwa dalam persamaan identitas $Y t=C t+I t+X-M$, di mana X-M merupakan Current Account (CA), sehingga $\mathrm{Yt}-\mathrm{Ct}-\mathrm{It}=\mathrm{Xt}-\mathrm{Mt}=\mathrm{CAt}$.

$$
\begin{aligned}
&-\mathrm{B}_{\mathrm{t}}=\mathrm{Y}_{\mathrm{t}}-\mathrm{C}_{\mathrm{t}}-\mathrm{I}_{\mathrm{t}}-\left(1+\mathrm{r}_{\mathrm{t}}\right) \mathrm{B}_{\mathrm{t}-1} \\
& \mathrm{~B}_{\mathrm{t}}=-\mathrm{CA}_{\mathrm{t}}+\left(1+\mathrm{r}_{\mathrm{t}}\right) \mathrm{B}_{\mathrm{t}-1} \\
& \mathrm{~B}_{\mathrm{t}+1}=-\mathrm{CA}_{\mathrm{t}+1}+\left(1+\mathrm{r}_{\mathrm{t}+1}\right) \mathrm{B}_{\mathrm{t}} \\
& \mathrm{B}_{\mathrm{t}+2}=-\mathrm{CA}_{\mathrm{t}+2}+\left(1+\mathrm{r}_{\mathrm{t}+2}\right) \mathrm{B}_{\mathrm{t}+1} \\
&=-\mathrm{CA}_{\mathrm{t}+2}+\left(1+\mathrm{r}_{\mathrm{t}+2}\right)\left[-\mathrm{CA}_{\mathrm{t}+1}+\left(1+\mathrm{r}_{\mathrm{t}+1}\right) \mathrm{B}_{\mathrm{t}}\right] \\
&=-\mathrm{CA}_{\mathrm{t}+2}-\left(1+\mathrm{r}_{\mathrm{t}+2}\right) \mathrm{CA}_{\mathrm{t}+1}+\left(1+\mathrm{r}_{\mathrm{t}+2}\right)\left(1+\mathrm{r}_{\mathrm{t}+1}\right) \mathrm{B}_{\mathrm{t}} \\
& B_{t}=\frac{C A_{t+1}}{\left(1+r_{t+1}\right)}+\frac{C A_{t+2}}{\left(1+r_{t+2}\right)\left(1+r_{t+1}\right)}+\frac{1}{\left(1+r_{t+2}\right)\left(1+r_{t+1}\right)} \\
& B_{t}=\frac{1}{\left(1+r_{t+(i-1)}\right)} C A_{t+(i-1)}+\frac{1}{\left(1+r_{t+i}\right)\left(1+r_{t+(i-1)}\right)} C A_{t+i} \\
& \quad+\frac{1}{\left(1+r_{t+n}\right)\left(1+r_{t+(n-1)}\right)} B_{t+n}
\end{aligned}
$$

Jika i $-1=\mathrm{j}$, dan $\mathrm{n}-1=\mathrm{p}$, maka:

$$
B_{t}=\frac{1}{\left(1+r_{t+j}\right)} C A_{t+(i-1)}+\frac{1}{\left(1+r_{t+i}\right)\left(1+r_{t+j}\right)} C A_{t+i}+\frac{1}{\left(1+r_{t+n}\right)\left(1+r_{t+p}\right)} B_{t+n}
$$

Apabila $\mu_{i}=\prod_{j=1}^{i} \frac{1}{1+r_{t+j}}$ dan $\mu_{n}=\prod_{p=1}^{n} \frac{1}{1+r_{t+p}}$ maka:

$$
B_{t}=\sum_{i=1}^{\infty} \mu_{i} C A_{t+i}+\sum_{n=1}^{\infty} \mu_{n} B_{t+n}
$$


$B_{t}=\sum_{i=1}^{\infty} \mu_{i} C A_{t+i}+\lim _{n \rightarrow \infty} \mu_{n} B_{t+n}$

di mana $\lim _{n \rightarrow \infty} \mu_{n} B_{t+n}=0$

\section{Sustainabilitas neraca transaksi berjalan}

$$
\begin{aligned}
& C_{t}=Y_{t}+B_{t}-I_{t}-\left(1+r_{t}\right) B_{t-1} \\
& -B_{t}+\left(1+r_{t}\right) B_{t-1}=Y_{t}-C_{t}-I_{t} \\
& -B_{t}+\left(1+r_{t}\right) B_{t-1}=X_{t}-M_{t} \\
& \left(1+r_{t}\right) B_{t-1}+M_{t}=X_{t}+B_{t}
\end{aligned}
$$

Dengan sedikit manipulasi, maka didapatkan:

$$
\begin{aligned}
& B_{t-1}+r_{t} B_{t-1}+r B_{t-1}-r B_{t-1}+M_{t}=X_{t}+B_{t} \\
& (1+r) B_{t-1}+\left(r_{t}-r\right) B_{t-1}+M_{t}=X_{t}+B_{t} \\
& \text { dimana }\left(r_{t}-r\right) B_{t-1}+M_{t}=Z_{t} \\
& \begin{array}{ll}
Z_{t}-X_{t}+(1+r) B_{t-1} & =B_{t} \\
Z_{t+1}-X_{t+1}+(1+r) B_{t} & =B_{t+1} \\
Z_{t+1}-X_{t+1}+(1+r)\left[Z_{t}-X_{t}+(1+r) B_{t-1}\right]=B_{t+1} \\
Z_{t+1}-X_{t+1}+(1+r)\left(Z_{t}-X_{t}\right)+(1+r)^{2} B_{t-1}=B_{t+1}
\end{array}
\end{aligned}
$$

Persamaan di atas sama bentuk dengan persamaan berikut:

$$
\begin{array}{r}
(1+r)^{1-1}\left(Z_{t+1}-X_{t+1}\right)+(1+r){ }^{1-0}\left(Z_{t+0}-X_{t+0}\right)+(1+r)^{2} B_{t-1}=B_{t+1} \\
\sum_{j=0}^{n}(1+r)^{n-j}\left(z_{t+j}-X_{t+j}\right)+(1+r)^{n+1} B_{t-1}=B_{t+n} ; \mathrm{n}=1 \text { dan } \mathrm{j}=0 \\
B_{t-1}=\frac{B_{t+n}}{(1+r)^{n+1}}+\sum_{j=0}^{n} \frac{(1+r)^{n-j} X_{t+j}-Z_{t+j}}{(1+r)^{n+1}} \\
B_{t-1}=\frac{1}{1+r^{n+1}} B_{t+n}+\sum_{j=0}^{n}(1+r)^{-j-1} X_{t+j}-Z_{t+j}
\end{array}
$$

Jika $\mu=\frac{1}{(1+r)}$ maka: $B_{t-1}=\mu^{n+1} B_{t+1}+\sum_{j=0}^{n} \mu^{j+1} X_{t+j}-Z_{t+j}$

Apabila $B_{t+n}$ dilimitkan:

$$
B_{t-1}=\lim _{n \rightarrow \infty} \mu^{n+1} B_{t+n}+\sum_{j=0}^{n} \mu^{j+1} X_{t+j}-Z_{t+j}
$$


Persamaan di atas dapat dimanipulasikan sebagai berikut:

$$
\begin{aligned}
& B_{t-1}=\sum_{j=0}^{n} \mu^{j+1} X_{t+j}-Z_{t+j}+\lim _{n \rightarrow \infty} \mu^{n+1} B_{t+n} \\
&= \mu\left(\mathrm{X}_{\mathrm{t}}-\mathrm{Z}_{\mathrm{t}}\right)+\mu^{2}\left(\mathrm{X}_{\mathrm{t}+1}-\mathrm{Z}_{\mathrm{t}+1}\right)+\mu^{3}\left(\mathrm{X}_{\mathrm{t}+2}-\mathrm{Z}_{\mathrm{t}+2}\right)+\ldots+\lim _{n \rightarrow \infty} \mu^{n+1} B_{t+n} \\
&= \mu\left(\mathrm{X}_{\mathrm{t}}-\mathrm{Z}_{\mathrm{t}}\right)+\mu^{2}\left(\mathrm{X}_{\mathrm{t}+1}-\mathrm{Z}_{\mathrm{t}+1}\right)-\mu^{2}\left(\mathrm{X}_{\mathrm{t}}-\mathrm{Z}_{\mathrm{t}}\right)+\mu^{2}\left(\mathrm{X}_{\mathrm{t}}-\mathrm{Z}_{\mathrm{t}}\right)+\mu^{3}\left(\mathrm{X}_{\mathrm{t}+2}-\mathrm{Z}_{\mathrm{t}+2}\right)- \\
& \mu^{3}\left(\mathrm{X}_{\mathrm{t}+1}-\mathrm{Z}_{\mathrm{t}+1}\right)+\mu^{3}\left(\mathrm{X}_{\mathrm{t}+1}-\mathrm{Z}_{\mathrm{t}+1}\right)+\ldots+\lim _{n \rightarrow \infty} \mu^{n+1} B_{t+n} \\
&= \mu\left(\mathrm{X}_{\mathrm{t}}-\mathrm{Z}_{\mathrm{t}}\right)+ \\
& \mu \sum_{j=1}^{\infty} \mu^{j}\left(\Delta X_{t+j}-\Delta Z_{t+j}\right)+\mu\left[\sum_{j=0}^{\infty} \mu^{j+1}\left(X_{t+j}-Z_{t+j}\right)+\lim _{n \rightarrow \infty} \quad \mu^{n+1} B_{t+n}-\right. \\
&\left.\lim { }_{n \rightarrow \infty} \mu^{n+1} B_{t+n}\right]+\lim _{n \rightarrow \infty} \mu^{n+1} B_{t+n} \\
&= \mu\left(\mathrm{X}_{\mathrm{t}}-\mathrm{Z}_{\mathrm{t}}\right)+\sum_{j=1}^{\infty} \mu^{j}\left(\Delta X_{t+j}-\Delta Z_{t+j}\right)+\mu \mathrm{B}_{\mathrm{t}-} \\
& 1-\mu\left[\lim _{n \rightarrow \infty} \mu^{n+1} B_{t+n}\right]+\lim _{n \rightarrow \infty} \mu^{n+1} B_{t+n} \\
&= \mu\left(\mathrm{X}_{\mathrm{t}}-\mathrm{Z}_{\mathrm{t}}\right)+\sum_{j=1}^{\infty} \mu^{j}\left(\Delta X_{t+j}-\Delta Z_{t+j}\right)+\mu \mathrm{B}_{\mathrm{t}-1}+(1-\mu) \lim _{n \rightarrow \infty} \mu^{n+1} B_{t+n}
\end{aligned}
$$

Dari sini, didapatkan:

$$
\frac{1-\mu}{\mu} B_{t-1}=X_{t}-Z_{t}+\sum_{j=1}^{\infty} \mu^{j}\left(\Delta X_{t+j}-\Delta Z_{t+j}\right)+\frac{1-\mu}{\mu} \lim _{n \rightarrow \infty} \mu^{n+1} B_{t+n}
$$

Jika $r=\frac{1-\mu}{\mu}$, maka:

$$
\mathrm{Z}_{\mathrm{t}}+\mathrm{rB} \mathrm{B}_{\mathrm{t}-1}=\mathrm{X}_{\mathrm{t}}+\sum_{\mathrm{j}=1}^{\infty} \mu^{\mathrm{j}}\left(\Delta \mathrm{X}_{\mathrm{t}+\mathrm{j}}-\Delta \mathrm{Z}_{\mathrm{t}+\mathrm{j}}\right)+\mathrm{r} \lim _{\mathrm{n} \rightarrow \infty} \mu^{\mathrm{n}+1} \mathrm{~B}_{\mathrm{t}+\mathrm{n}}
$$

Asumsikan bahwa $X_{t}$ dan $Z_{t}$ merupakan variabel random walk dengan

$$
\begin{aligned}
& \mathrm{X}_{\mathrm{t}}=\mathrm{a}_{1}+\mathrm{X}_{\mathrm{t}-1}+\varepsilon_{1 \mathrm{t}} \operatorname{dan} \mathrm{Z}_{\mathrm{t}}=\mathrm{a}_{2}+\mathrm{Z}_{\mathrm{t}-1}+\varepsilon_{2 \mathrm{t}} ; \\
& \mathrm{Z}_{\mathrm{t}}+\mathrm{rB} \mathrm{t}_{\mathrm{t}-1}=\mathrm{X}_{\mathrm{t}}+\sum_{j=1}^{\infty} \mu^{j}\left[\mathrm{a}_{1}-\mathrm{a}_{2}+\varepsilon_{1, \mathrm{t}+\mathrm{j}}-\varepsilon_{2, \mathrm{t}+\mathrm{j}}\right]+r \lim _{n \rightarrow \infty} \mu^{n+1} B_{t+n} \\
& \quad=\mathrm{X}_{\mathrm{t}}+\alpha_{1}-\alpha_{2}+\sum_{j=1}^{\infty} \mu^{j}\left[\varepsilon_{1, \mathrm{t}+\mathrm{j}}-\varepsilon_{2, \mathrm{t}+\mathrm{j}}\right]+r \lim _{n \rightarrow \infty} \mu^{n+1} B_{t+n}
\end{aligned}
$$

Karena: $\left(r_{t}-r\right) B_{t-1}+M_{t}=Z_{t}$

$$
\begin{aligned}
& r_{t} B_{t-1}-r B_{t-1}+M_{t}+r B_{t-1}=X_{t}+\alpha_{1}-\alpha_{2}+\sum_{j=1}^{\infty} \mu^{j}\left[\varepsilon_{1, t+j} \varepsilon_{2, t+j}\right]+r \lim _{n \rightarrow \infty} \mu^{n+1} B_{t+n} \\
& r_{t} B_{t-1}+M_{t}=X_{t}+\alpha_{1}-\alpha_{2}+\sum_{j=1}^{\infty} \mu^{j}\left[\varepsilon_{1, t+j}-\varepsilon_{2, t+j}\right]+r \lim _{n \rightarrow \infty} \mu^{n+1} B_{t+n}
\end{aligned}
$$

Asumsikan $\lim _{n \rightarrow \infty} \mu^{n+1} B_{t+n}=0, \alpha=\alpha_{1}-\alpha_{2}$ dan $\varepsilon_{t}=\sum_{j=1}^{\infty} \mu^{j}\left[\varepsilon_{1, t+j}-\varepsilon_{2, t+j}\right]$, serta $\mathrm{MM}_{\mathrm{t}}=\mathrm{r}_{\mathrm{t}} \mathrm{B}_{\mathrm{t}-1}+\mathrm{M}_{\mathrm{t}}$, maka:

$$
\mathrm{X}_{\mathrm{t}}=\alpha+\mathrm{MM}_{\mathrm{t}}+\varepsilon_{\mathrm{t}}
$$

